\title{
VARIETIES, SEEDING STANDARDS AND CROP PROTECTION AS FACTORS AFFECTING THE CONTENT OF MICROELEMENTS IN SPELT WINTER WHEAT (Triticum aestivum ssp. spelta L.) GRAIN
}

\section{ODMIANY, NORMY WYSIEWU I OCHRONA ŁANU JAKO CZYNNIKI MAJACCE WPŁYW NA ZAWARTOŚĆ MIKROSKŁADNIKÓW W ZIARNIE OZIMEGO ORKISZU PSZENNEGO (Triticum aestivum ssp. spelta L.)}

\author{
Department of Agronomy, West Pomeranian University of Technology, Szczecin, Poland \\ 1Department of Herbology and Plant Cultivation Techniques, University of Life Sciences \\ in Lublin, Poland
}

\begin{abstract}
Streszczenie. Cel realizowanych badań stanowiło określenie wpływu: sposobu ochrony łanu i norm wysiewu na zawartość mikroskładników (żelazo, cynk, mangan, miedź, nikiel, kadm, ołów) w ziarnie dwóch odmian orkiszu - polskiej ‘Rokosz' i niemieckiej 'Schwabenspelz'. Doświadczenie polowe przeprowadzono w latach 2014-2015 w miejscowości Czesławice w gospodarstwie doświadczalnym należącym do Uniwersytetu Przyrodniczego w Lublinie. Doświadczenie założono na glebie płowej wytworzonej z lessu, zaliczanej do II klasy bonitacyjnej. Materiał do analizy stanowiło ziarno ozimego orkiszu pszennego. W badaniach porównywano trzy czynniki: Pierwszym czynnikiem były odmiany orkiszu, drugim - ilość wysiewu, trzecim - ochrona łanu. Zawartość w ziarnie ozimego orkiszu pszennego czterech mikroskładników: żelaza, manganu, cynku i miedzi różnicował czynnik odmianowy. Porównywane odmiany nie różnicowały ilości niklu w ziarnie orkiszu ozimego. Odmiana 'Schwabenpeltz' jest bardziej zasobna niż odmiana 'Rokosz', co wynika głównie z wyraźnie większej ilości żelaza w ziarnie odmiany niemieckiej. Stosunek wagowy $\mathrm{Fe}$ : Mn w ziarnie orkiszu ozimego odmiany 'Schwabenspelz' wynosi 2,7, co może wskazywać na pewien brak manganu, przy jednoczesnym nadmiarze żelaza. Zwiększenie obsady roślin na jednostce powierzchni spowodowało udowodnione statystycznie obniżenie zawartości żelaza, manganu i cynku, ale nie wpłynęło na zasobność ziarna orkiszu w stosunku do miedzi i niklu. Otrzymane wyniki nie wykazują istotnego wpływu sposobu ochrony łanu na zawartość mikro-składników w ziarnie orkiszu ozimego, z wyjątkiem miedzi. Zastosowanie herbicydów w zwiększonej dawce spowodowało zmniejszenie ilości miedzi poniżej $3 \mathrm{mg} \mathrm{Cu} \cdot \mathrm{kg}^{-1} \mathrm{~s} . \mathrm{m}$.
\end{abstract}

Key words: winter spelt varieties (Triticum aestivum ssp. spelta L.), microelements, crop protection, standards sowing, variety.

Słowa kluczowe: pszenica ozima typu orkisz (Triticum aestivum ssp. spelta L.), makroskładniki, ochrona łanu, ilość wysiewu, odmiany.

\section{INTRODUCTION}

Microelements are defined as elements occurring at plants in small quantities, but essential for their development, and trace elements as all the elements present at low concentrations, even those biologically inactive (Lityński and Jurkowska 1982). Microelements are both

Corresponding author - Adres do korespondencji: Grzegorz Hury, Department of Agronomy, West Pomeranian University of Technology, Szczecin, Papieża Pawła VI 3, 71-459 Szczecin, Poland, e-mail: Grzegorz.Hury@zut.edu.pl. 
necessary for the development and functioning of a human organism and when present at excessive concentrations, they may cause adverse effects (Plants and the Chemical Elements... 2008). Whole-grain cereal products are one of the main sources of microelements in human diet, and wheat is the cereal of key importance.

In recent years in Poland, there has been increasing interest in the cultivation of winter wheat of spelt type (Triticum aestivum ssp. spelta L.) - species already known in the Neolithic period and the Bronze Age (8000-3000 BC). Renaissance of this grain cultivation occurred in the last two decades. Winter spelt wheat (Triticum aestivum ssp. spelta L.) is commonly referred to as spelt. Popular for centuries in Europe, was replaced in the nineteenth century by increasingly cultivated wheat. Due to the fact that spelt is not subjected to genetic modifications, it retains its original features. An important feature in the assessment of spelt nutritional values is the amount of minerals. In a series of papers on the chemical composition of spelt grain, there are presented information that the mineral content in spelt grain is differentiated by varietal factor (Sawicka and Krochmal-Marczak 2014; Stankowski et al. 2016; Stępień et al. 2016). High contents of iron and zinc, as well as copper, manganese, cobalt, and selenium are mentioned most often (Baumagärtel-Blaschke 1991; Tyburski and Babalski 2006). Kraska et al. (2013), when analyzing the influence of chemical crop protection on the contents of some elements in grain of eight spelt varieties underlined that they differed with such elements as zinc, copper, iron, and manganese.

List of Crop Varieties entered into the national register in Poland in 2015, includes 85 winter wheat varieties and only one spelt variety called 'Rokosz' (name of the breeder STH 4809, date of entry March 2012). Varieties grown in Poland originate mainly from Germany (Gacek 2015). Spelt variety 'Schwabenspelz' is older than 'Rokosz', and it was entered the German descriptive national register in 2000 (Beschreibende Sortenliste Getreide... 2005). Many factors such as climate, agricultural practices, the use of plant protection products, or the specifics of varieties, all have influence on the mineral content of the crops grown (Tyburski and Babalski 2006; Błaziak 2007; Kraska et al. 2013; Żuk-Gołaszewska 2015).

The aim of the research was the impact analysis of the effect of crop protection and seeding standards on the contents of micronutrients (iron, zinc, manganese, copper, nickel, cadmium, lead) in grain of two spelt varieties: Polish 'Rokosz' and German 'Schwabenspelz'.

\section{MATERIAL AND METHODS}

\section{Conditions of the experiment conducting}

The field experiment was conducted in 2014-2015 in Czesławice ( $\left.\varphi=51^{\circ} 30^{\prime} \mathrm{N}, \lambda=22^{\circ} 28^{\prime} \mathrm{S}\right)$, at the Experimental Farm of University of Life Sciences in Lublin. The experiment was established on lessove soil developed from loess classified as good wheat complex and second bonitation class, slightly acidic (PN-ISO 10390 : 1997P) and humus content of $16.3 \mathrm{~g} \cdot \mathrm{kg}^{-1}$ soil.

Material for analyses consisted of winter spelt grain obtained as an average from triplicates.

The studies compared three factors:

- factor I: winter spelt varieties ('Rokosz' cv., 'Schwabenspelz' cv.);

- factor II: two seeding rates standards:

$130 \mathrm{~kg} \cdot \mathrm{ha}^{-1}$ of 'Rokosz' cv. kernels and $200 \mathrm{~kg} \cdot \mathrm{ha}^{-1}$ of 'Schwabenspelz' cv. spikelets, $200 \mathrm{~kg} \cdot \mathrm{ha}^{-1}$ of 'Rokosz' cv. kernels and $350 \mathrm{~kg} \cdot \mathrm{ha}^{-1}$ of 'Schwabenspelz' cv. Spikelets; 
- factor III: crop protection:

A - control object (no protection);

$B$ - harrowing in early spring after the start of vegetation;

C - use of herbicides: Sekator 125 OD (amidosulfuron, methyl-sodium iodosulfuron) at the stage $\mathrm{BBCH}-22-24$ at rate $150 \mathrm{~cm}^{3} \cdot \mathrm{ha}^{-1}$, and Attribut 70WG (sodium propoxykarbazon) at stage $\mathrm{BBCH}-22-24$ at rate $60 \mathrm{~cm}^{3} \cdot \mathrm{ha}^{-1}$;

D - use of herbicides: Sekator 125 OD (amidosulfuron, methyl-sodium iodosulfuron) at the stage $\mathrm{BBCH}-22-24$ at rate $150 \mathrm{~cm}^{3} \cdot \mathrm{ha}^{-1}$, and Attribut 70WG (sodium propoxycarbazon) at stage $\mathrm{BBCH}-22-24$ at rate $60 \mathrm{~cm}^{3} \cdot \mathrm{ha}^{-1}$, anti-lodging agent Cerone $480 \mathrm{SL}$ (etephone) at stage $\mathrm{BBCH}-30-31$ at rate $0.75 \mathrm{dm}^{3} \cdot \mathrm{ha}^{-1}$, fungicide Wirtuoz $520 \mathrm{EC}$ (prochloraz, tebuconasole, proquinaside) at stages $\mathrm{BBCH}-24-25$ and $32-33$ at rate $1.0 \mathrm{dm}^{3} \cdot \mathrm{ha}^{-1}$, insecticide Decis 2,5 EC (deltametrin) at stage $\mathrm{BBCH}-37-39$ at rate $0.25 \mathrm{dm}^{3} \cdot \mathrm{ha}^{-1}$.

In each year of the study, winter wheat was grown as a fore crop. Mineral fertilizers were applied in the following doses: $50 \mathrm{~kg} \mathrm{~N} \cdot \mathrm{ha}^{-1}, 26 \mathrm{~kg} \mathrm{P} \cdot \mathrm{ha}^{-1}$ and $50 \mathrm{~kg} \mathrm{~K} \cdot \mathrm{ha}^{-1}$. The entire amount of phosphorus, potassium and nitrogen fertilizers at rate of $20 \mathrm{~kg} \mathrm{~N} \cdot \mathrm{ha}^{-1}$ was applied before spelt sowing. The remaining amount of nitrogen fertilizer was used in the spring right after the start of vegetation. Plot surface to sow and harvest was $13.5 \mathrm{~m}^{2}(5 \mathrm{~m} \times 2.7 \mathrm{~m})$. Spelt was sown in the last decade of September. Ploughing tillage was typical for growing wheat. A harvest was performed at full maturity stage of grain.

After spelt grain digestion in mixture of nitric $(\mathrm{V})$ and chloric(VII) acids at the ratio of $1: 1$, a total contents of iron, manganese, zinc, copper, nickel, cadmium, and lead were determined using AAS system (Thermo Fisher Scientific ICE 3000 Series).

\section{Climatic conditions}

The average temperature recorded in the period of plant growth in 2013 and 2014, according to Meteorological Station in Czesławice, was much higher than the multi-year average. The vegetation period in 2015 was characterized by a temperature close to the average for 1963-2010.

Total rainfall during the growing season in 2013 and 2014 was higher by $34 \%$ as compared to the rainfall for 40 years, which is the basis for evaluation of this period as very humid. A particularly large amount of rainfall was recorded in May, June and August 2014. In 2015, the amount of rainfall was lower than that recorded in many-year period - the growing season can be classified as dry (85.5\% of the average value) - Kaczorowska (1962).

\section{Statistical analysis}

The results were statistically analysed with the use of analysis of variance of a completely randomised design. Replications were results from 2 years of investigation. Tukey's range test were calculated at the level $p=0.05$. The statistical analysis of the results was conducted using Statistca 10 software.

\section{RESULTS AND DISCUSSION}

\section{Winter spelt varieties}

The chemical composition of plants is genetically determined; it is also a subject to fluctuations depending on external factors, a given plantation exist (Wojtala-Łozowska and Parylak 2009). In general, quality of wheat grain is the result of genetic characteristics, soil and 
climate conditions, and applied agricultural operations. Plants uptake micronutrients in small quantities, which by stimulating biochemical processes, activate a variety of physiological processes. The role of microelements cannot be underestimated.

Table 1. Contents of micronutrients in winter spelt grain $\left[\mathrm{mg} \cdot \mathrm{kg}^{-1} \mathrm{DM}\right]$ depending on the variety Tabela 1. Zawartość mikroskładników w ziarnie orkiszu ozimego $\left[\mathrm{mg} \cdot \mathrm{kg}^{-1} \mathrm{~s}\right.$.m.] w zależności od odmiany

\begin{tabular}{|c|c|c|c|c|}
\hline \multirow{2}{*}{$\begin{array}{l}\text { Microelements } \\
\text { Mikroskładnik }\end{array}$} & \multicolumn{2}{|c|}{ Variety - Odmiana } & \multirow{2}{*}{$\begin{array}{c}\text { Mean } \\
\text { Średnia }\end{array}$} & \multirow{2}{*}{$\mathrm{HSD}_{0.05}$ for - dla } \\
\hline & 'Rokosz' & 'Schwabenspelz' & & \\
\hline Iron - Żelazo (Fe) & 25.8 & 31.6 & 28.7 & 1.839 \\
\hline Manganese - Mangan (Mn) & 13.3 & 11.8 & 12.6 & 1.187 \\
\hline Zinc - Cynk (Zn) & 18.6 & 17.2 & 17.9 & 1.353 \\
\hline Copper - Miedź (Cu) & 2.87 & 3.11 & 2.99 & 0.125 \\
\hline Nickel - Nikiel (Ni) & 0.519 & 0.570 & 0.545 & n.s. \\
\hline
\end{tabular}

n.s. - not significant difference - różnica nieistotna.

HSD - the slightest difference - najmniejsza istotna różnica.

Abundance of spelt grain regarding iron is important because of the functions this element plays in living organisms. Its function as the promoter in synthesis of chlorophyll and certain proteins is especially important. Szteke et al. (2004) studying in 2001-2003 the iron content in grain of wheat grown in Poland reported results in a vast range from 18.7 to $167.0 \mathrm{mg} \mathrm{Fe} \cdot \mathrm{kg}^{-1}$ DM. Iron concentration determined in analyzed material ranged within these limits. Grain of spelt grown in present experiment contained $28.7 \mathrm{mg} \mathrm{Fe} \cdot \mathrm{kg}^{-1} \mathrm{DM}$, on average, and German variety was characterized by significantly higher contents of this metal (Table 1). The obtained dependency is confirmed by the results presented by Zhaoa et al. (2009) and Singh et al. (2012). Manganese is the nutrient essential for plant life, being a regulator and stimulator of growth and is important for various oxidation-reduction processes. Manganese forms labile complexes with certain enzymes or ATP acting as an ionic bridge between the substrate and the enzyme. It participates in the processes of photosynthesis and respiration, metabolism of proteins, carbohydrates and lipids, as well as elimination of free radicals (Stadtman et al. 1990). Szteke et al. (2004) studying in 2001-2003 the iron content in grain of wheat grown in Poland reported results in a wide range from 9.2 to $69.1 \mathrm{mg} \mathrm{Mn} \cdot \mathrm{kg}^{-1} \mathrm{DM}$. Average manganese concentration in winter spelt grain grown in the experiment was at the level of $12.6 \mathrm{mg} \mathrm{Mn} \cdot \mathrm{kg}^{-1} \mathrm{DM}$ and Polish variety was more abundant (Table 1).

Manganese at plants occurs at different oxidation states from 2 to 7 , while iron only at 2 and 3 . Increasing the uptake of one of the components causes a reduction in acquiring of other and, in this context, manganese and iron may act as biochemical antagonists and can compete for the uptake (Gudmundsdóttir et al. 2006). Iron deficit is sometimes accompanied by symptoms of manganese toxicity. Iron to manganese ratios for various plant species fall within wide limits and are the indicator of a proper supply of plants with these micronutrients. In order to compare their contents, only weight ratio can be applied, which is a simple quotient of their quantities at plants due to the fact that these elements are present in plants at various degrees of oxidation. The Fe : Mn ratio in plant tissue should range within 1.5-2.5. Below 1.5, manganese toxicity and iron deficiency symptoms can be visible, and above 2.5, iron excess is hazardous, which is accompanied by manganese deficiency indications (Błaziak 2007). Weight ratio of Fe: Mn in winter spelt grain of 'Rokosz' cv. was 1.9, and for 'Schwabenspelz' cv. it was 2.7, which may be a some indicator of manganese lack at the excess of iron. 
Zinc affects the process of plant growth and development, allows the metabolism of carbohydrates and is required for the synthesis of many proteins, phosphates and vitamins (Lindsay 1972). The literature presents a wide range of zinc contents in winter spelt grain. According to Kabata-Pendias (2011), average zinc content in common wheat grain amounts to $24 \mathrm{mg} \cdot \mathrm{Zn} \mathrm{kg}^{-1}$. In studies by Pałys and Łabuda (1997), concentration of zinc in grain of evaluated spelt varieties was from 16.0 to $25.0 \mathrm{mg} \mathrm{kg}^{-1}$ DM. Kraska et al. (2013), based on own study, found mean zinc content in spelt wheat of $41 \mathrm{mg} \mathrm{Zn} \cdot \mathrm{kg}^{-1} \mathrm{DM}$. The highest zinc quantity was recorded in grain of Bauländer Spelz cv., $51.3 \mathrm{mg} \mathrm{Zn} \cdot \mathrm{kg}^{-1} \mathrm{DM}$ (Grela 1996).

In present study, average zinc content in grain of tested spelt varieties was relatively low amounting to $17.9 \mathrm{mg} \mathrm{Zn} \cdot \mathrm{kg}^{-1} \mathrm{DM}$. Statistical analysis confirmed the impact of a variety on the zinc quantity in spelt grain; grain of 'Rokosz' cv. was more abundant (Table 1).

Both zinc and copper are among the transition metals in the Periodic Table. Relationship between copper and zinc uptake are widely discussed in the literature. Metals are absorbed by a similar mechanism and may mutually inhibit absorption through the root system (Graham 1981). Results achieved in present experiment indicated that copper amounts in spelt grain were 2.87 and $3.11 \mathrm{mg} \mathrm{Cu} \cdot \mathrm{kg}^{-1} \mathrm{DM}$, respectively for 'Rokosz' cv. and 'Schwabenspelz' cv. and these values are about 5-fold lower than those for zinc (Table 1). Żuk-Gołaszewska et al. (2015), performing a study on the physio-agronomic performance of spring cultivars $T$. aestivum and $T$. spelta grown in organic farming system, obtained a higher content of copper in spelt seeds of Roter and Speltz cultivars 5.15 and $4.37 \mathrm{mg} \mathrm{Cu} \cdot \mathrm{kg}^{-1} \mathrm{DM}$ respectively.

Nickel is also classified to transition metals, the common feature of which is incomplete filling of electron shells. Nickel being a heavy metal of a moderate potential hazard, is included into the list of micronutrients. The content of this element in our country's grain cereals, according to Kabata-Pendias (2011), amounts to $0.1-5 \mathrm{mg} \cdot \mathrm{kg}^{-1} \mathrm{DM}$. Kaszubkiewicz and Kawałko (2009) reported that average content in cereal grain for nickel is $0.77 \mathrm{mg} \mathrm{Ni} \cdot \mathrm{kg}^{-1} \mathrm{DM}$. In present study, nickel concentration in winter spelt grain was on average: $0.54 \mathrm{mg} \cdot \mathrm{kg}^{-1} \mathrm{DM}$, which was relatively low. Compared varieties did not differentiate nickel content in winter spelt grain (Table 1).

Regulations of the Commission of the European Union determine the levels of cadmium and lead in foodstuffs, however, winter spelt grain examined in the experiment did not contain these elements.

Comparison of the total contents of micronutrients in grain of tested varieties reveals that 'Schwabenpeltz' cv. is more abundant and the difference amounts to $3.21 \mathrm{mg} \cdot \mathrm{kg}^{-1} \mathrm{DM}$. It is clearly the result of higher iron level in grain of German variety.

\section{Two seeding standards}

Seeding density is a factor that contributes significantly to the quality of harvested grain yield. Generally, in German conditions, recommended seeding density for spelt is from 200 to $250 \mathrm{~kg}$ per hectare.

Changing the amount of plant density did not affect only the spelt grain abundance in respect of copper and nickel. Increasing the plant density resulted in a statistically proven decrease in the amount of grain in three determined micronutrients: iron, manganese and zinc, which caused that grain of plants growing at an optimal seeding density contained higher sum of micronutrients (difference $5.5 \mathrm{mg} \cdot \mathrm{kg}^{-1} \mathrm{DM}$ ) - Table 2. 
Table 2. Micronutrients content in winter spelt grain [mg $\left.\cdot \mathrm{kg}^{-1} \mathrm{DM}\right]$ depending on plant density Tabela 2. Zawartość mikroskładników w ziarnie orkiszu ozimego [ $\mathrm{mg} \cdot \mathrm{kg}^{-1} \mathrm{~s} . \mathrm{m}$.] w zależności od obsady roślin

\begin{tabular}{|c|c|c|c|c|}
\hline \multirow{2}{*}{$\begin{array}{l}\text { Microelements } \\
\text { Mikroskładnik }\end{array}$} & \multicolumn{2}{|c|}{ Obsada roślin - Plants denisity } & \multirow{2}{*}{$\begin{array}{l}\text { Mean } \\
\text { Średnia }\end{array}$} & \multirow[b]{2}{*}{$\mathrm{HSD}_{0.05}$ for - dla } \\
\hline & $\begin{array}{c}\text { optimal } \\
\text { optymalna }\end{array}$ & $\begin{array}{c}\text { increased } \\
\text { podwyższona }\end{array}$ & & \\
\hline Iron -Żelazo (Fe) & 29.7 & 27.7 & 28.7 & 1.839 \\
\hline Manganese - Mangan (Mn) & 13.3 & 11.9 & 12.6 & 1.187 \\
\hline Zinc - Cynk (Zn) & 18.7 & 17.1 & 17.9 & 1.353 \\
\hline Copper - Miedź (Cu) & 3.00 & 2.99 & 2.99 & n.s. \\
\hline Nickel - Nikiel (Ni) & 0.549 & 0.540 & 0.545 & n.s. \\
\hline Sum - Suma & 65.5 & 60.3 & 62.7 & - \\
\hline
\end{tabular}

n.s. - not significant difference - różnica nieistotna.

HSD - the slightest difference - najmniejsza istotna różnica.

\section{Crop protection}

The literature often gives an information that spelt is resistant to certain cereal diseases and does not require fungicides, however, the use of synthetic plant protection products is an integral part of modern agriculture. This creates a need to control their impact on the quality of crops, since these agents may affect the metabolism of plants, which also causes changes in grain quality (Mularczyk et al. 2010). The experiment compared the use of herbicides with harrowing in early spring after the start of vegetation, intended to kill overwintering or survival stages.

Table 3. Micronutrients content in winter spelt grain [ $\left.\mathrm{mg} \cdot \mathrm{kg}^{-1} \mathrm{DM}\right]$ depending on the crop protection Tabela 3. Zawartość mikroskładników w ziarnie orkiszu ozimego [mg $\cdot \mathrm{kg}^{-1} \mathrm{~s} . \mathrm{m}$.] w zależności od ochrony łanu

\begin{tabular}{|c|c|c|c|c|c|c|}
\hline \multirow{2}{*}{$\begin{array}{l}\text { Microelements } \\
\text { Mikroskładnik }\end{array}$} & \multicolumn{4}{|c|}{ Crop protection - Ochrona łanu } & \multirow{2}{*}{$\begin{array}{c}\text { Mean } \\
\text { Średnia }\end{array}$} & \multirow{2}{*}{$\begin{array}{l}\mathrm{HSD}_{0.05} \\
\text { for - dla }\end{array}$} \\
\hline & A & $\mathrm{B}$ & $\mathrm{C}$ & $\mathrm{D}$ & & \\
\hline Iron - Żelazo (Fe) & 29.2 & 27.3 & 29.3 & 29.0 & 28.7 & n.s. \\
\hline Manganese - Mangan (Mn) & 13.0 & 11.4 & 13.1 & 12.8 & 12.6 & n.s. \\
\hline Zinc - Cynk (Zn) & 18.1 & 17.1 & 18.2 & 18.0 & 17.9 & n.s. \\
\hline Copper - Miedź (Cu) & 3.09 & 3.05 & 3.09 & 2.74 & 2.99 & 0.235 \\
\hline Nickel - Nikiel (Ni) & 0.527 & 0.496 & 0.514 & 0.641 & 0.545 & n.s. \\
\hline Sum - Suma & 63.9 & 59.3 & 64.2 & 63.2 & 62.7 & - \\
\hline
\end{tabular}

n.s. - not significant difference - różnica nieistotna.

HSD - the slightest difference - najmniejsza istotna różnica.

A - control object - obiekt kontrolny, B - harrowing in early spring - bronowanie wczesną wiosną, C - use of herbicides: Sekator 125 OD, Attribut 70WG - zastosowanie herbicydów: Sekator 125 OD, Attribut 70WG, D - use of herbicides: Sekator $125 \mathrm{OD}$, Attribut 70WG, anti-lodging agent Cerone $480 \mathrm{SL}$, fungicide Wirtuoz 520 EC, insecticide Decis 2,5 EC - zastosowanie herbicydów: Sekator 125 OD, Attribut 70WG, regulatora wzrostu Cerone $480 \mathrm{SL}$, fungicydu Wirtuoz $520 \mathrm{EC}$, insektycydu Decis 2,5 EC.

Results obtained in the experiment, that were subjected to statistical analysis, showed no significant effect of the crop protection method on the contents of four macronutrients in winter spelt grain. These were iron, manganese, zinc and nickel (Table 3). The use of herbicides at an increased dose reduced the amount of copper in winter spelt grain to a level below $3 \mathrm{mg} \mathrm{Cu} \cdot \mathrm{kg}^{-1} \mathrm{DM}$.

\section{CONCLUSIONS}

1. The content of four microelements in winter spelt grain: iron, manganese, zinc and copper, was differentiated by varietal factor. 
2. Comparing the overall content of micronutrients in grain of tested varieties, it should be noted that 'Schwabenpeltz' cv. is more abundant than 'Rokosz' cv., and the difference is $3.21 \mathrm{~g} \cdot \mathrm{kg}^{-1} \mathrm{DM}$. This is mainly because of clearly more iron in the grain of German variety. The weight ratio of $\mathrm{Fe}: \mathrm{Mn}$ in winter spelt grain of 'Schwabenspelz' cv. is 2.7, which may indicate a lack of manganese while the excess of iron.

3. Increasing the plant denisity resulted in a statistically proven reduction in the content of iron, manganese and zinc in winter spelt grain. Changing the amount of plant density did not affect the spelt grain abundance in relation to copper and nickel.

4. Results obtained in the experiment showed no significant effect of the crop protection method on content of microelements in winter spelt grain with the exception of copper. The use of herbicides at an increased dose reduced the amount of copper below $3 \mathrm{mg} \mathrm{Cu} \cdot \mathrm{kg}^{-1} \mathrm{DM}$.

\section{REFERENCES}

Baumagärtel-Blaschke U. 1991. Dinkel für die neue deutsche Küche. DLG - Mitteilungen 106(12), 44-47.

Beschreibende Sortenliste Getreide, Mais, Ölfrüchte, Leguminosen, Hackfrüchte. 2005. Ed. Bundessortenamt/BSA. Hannover, Landbuch Verlagsgesellschaft.

Błaziak J. 2007. Ocena zmian zawartości mikroelementów w zbożach pod wpływem wapnowania i magnezowania gleby [Evaluation of the content of micronutrients in cereals under the influence of liming and magnesium enrichment of soil]. Ann. UMCS, Sec. E Agricultura 62(1), 77-84. [in Polish]

Gacek E.S. 2015. Lista odmian roślin rolniczych wpisanych do krajowego rejestru w Polsce. Słupia Wielka, COBORU, 1-78. [in Polish]

Graham R.D. 1981. Absorption of copper by plant roots, in: Copper in soils and plants. Ed. J.F. Loneragan, A.D. Robson, R.D. Graham. New York, Academic Press, 141.

Grela E.R. 1996. Nutrient composition and content of antinutritional factors in spelt (Triticum spelta L.) cultivars. J. Sci. Food Agric. 71, 399-404.

Gudmundsdóttir K.B., Sigurdarson S., Kristinsson J., Eiríksson T., Jóhannesson T. 2006. Iron and iron/manganese ratio in forage from Icelandic sheep farms: relation to scrapie. Scand. Veter. Acta. 48, 16-21.

Kabata-Pendias A. 2011. Trace elements in soil and plants, 4th ed. [b.m.], CRC Press, Taylor \& Francis Group. USA, 1-548.

Kaczorowska Z. 1962. Opady w Polsce w przekroju wieloletnim [Precipitation in Poland in long-period averages]. Pr. Geogr. 33, 107. [in Polish]

Kaszubkiewicz J., Kawałko D. 2009. Zawartość wybranych metali ciężkich w glebach i roślinach na terenie powiatu jeleniogórskiego [Heavy metal content in soils and plants in the district of Jelenia Gora]. Ochr. Środ. Zas. Natur. 40, 177-189. [in Polish]

Kraska P., Andruszczak S., Kwiecińska-Poppe E., Pałys E. 2013. Effect of chemical crop protection on the content of some elements in grain of spelt wheat (Triticum aestivum ssp. spelta). J. Elem. 18(1), 79-90.

Lindsay W.L. 1972. Zinc in soils and plant nutrition. Adv. Agron. 24, 147-186.

Lityński T., Jurkowska H. 1982. Żyzność gleby i odżywianie się roślin. Warszawa, PWN, 146-279. ISBN 8301028874. [in Polish]

Mularczyk A., Narkiewicz-Jodko M., Gil Z., Urban M. 2010. Wpływ herbicydów na zdrowotność i jakość ziarna pszenicy ozimej na tle warunków pogodowych [The influence of herbicides on health and quality of winter wheat grain depending on weather conditions]. Prog. Plant Prot. 50(1), 482-490. [in Polish]

Pałys E., Łabuda S. 1997. Yielding and elemental composition of spelt wheat grain and strow. Rachis 16(1/2), 67-70. 
Plants and the chemical elements. Biochemistry, uptake, tolerance and toxicity. 2008. Ed. M.E. Farago. [b.m.], Wiley-Blackwell. US, 1-302. ISBN 978-3-527-61590-2.

PN-ISO 10390 : 1997P. Soil quality - Determination of $\mathrm{pH}$.

Sawicka B., Krochmal-Marczak B. 2014. Pszenica orkiszowa (Triticum aestivum ssp. spelta) jako alternatywa dla gospodarstw ekologicznych, w: Współczesne dylematy polskiego rolnictwa. Red. K. Zarzecka, S. Kondracki, J. Skrzyczyńska J. Biała Podlaska, PWS JPII, 344-357. [in Polish]

Singh S.K., Gupta A.K., Kaur N. 2012. Influence of drought and sowing time on protein composition, antinutrients, and mineral contents of wheat. Sci. World J., 1-9. DOI:10.1100/2012/485751.

Stadtman E.R., Berlett B.S., Chock P.B. 1990. Manganese-dependent disproportionation of hydrogen peroxide in bicarbonate buffer. Proc. Natl. Acad. Sci. USA 87, 384-388.

Stankowski S., Hury G., Makrewicz A., Jurgiel-Małecka G., Gibczyńska M. 2016. Analiza zawartości składników mineralnych w ziarnie orkiszu ozimego (Triticum Aestivum ssp spelta L.) w zależności od systemu uprawy, nawożenia azotowego i odmiany [Analysis of the content of mineral components in grain of winter spelt (Triticum Aestivum ssp spelta L.) depending on: tillage system, fertilization nitrogen and variety]. Inż. Ekolog. 49, 227-232. [in Polish]

Stępień A., Wojtkowiak K., Orzech K., Wiktorski A. 2016. Nutritional and technological characteristics of common and spelt wheats are affected by mineral fertilizer and organic stimulator nano-gro. Acta Sci. Pol., Agricultura 15(2), 49-63. ISSN 1644-0625.

Szteke B., Jędrzejczak R., Ręczajska W. 2004. Zawartość żelaza i manganu w wybranych roślinach jadalnych [The content of iron and manganese in some plants edible]. Rocz. PZH 55 (Suppl.) 21-27. [in Polish]

Tyburski J., Babalski M. 2006. Uprawa pszenicy orkisz poradnik dla rolników. Radom, CDR w Brwinowie Oddział w Radomiu. 1-25. [in Polish]

Wojtala-Łozowska L., Parylak D. 2009. Wpływ odmiany i zaprawiania materiału siewnego na zawartość i pobranie mikroelementów w ziarnie pszenicy ozimej [The influence of cultivar and seed treatment on content and taken of microelements in grain of winter wheat]. Zesz. Nauk. UP Wroc., Rolnictwo 95(574), 117-124. [in Polish]

Zhaoa F.J., Sua Y.H., Dunhama S.J., Rakszegib M., Bedob Z., McGratha S.P., Shewryc P.R. 2009. Variation in mineral micronutrient concentrations in grain of wheat lines of diverse origin. J. Cereal Sci. 49, 290-295.

Żuk-Gołaszewska K., Kurowski T., Załuski D., Sadowska M., Gołaszewski J. 2015. Physio-agronomic performance of spring cultivars $T$. aestivum and $T$. spelta grown in organic farming system. Int. J. Plant Prod. 9, 212-236.

\begin{abstract}
The aim of the study was to evaluate the effect of crop protection and seeding standards on the contents of microelements (iron, zinc, manganese, copper, nickel, cadmium, lead) in grain of two spelt varieties: Polish 'Rokosz' and German 'Schwabenspelz'. The field experiment was conducted in Czesławice in 2014-2015 at the Experimental University of Life Sciences in Lublin. Experiments were established on lessive soil developed from loess classified to II bonitation class. Material for analysis consisted of winter spelt grain. Three factors were compared during the study: first factor - winter spelt varieties, second factor - two seeding standards, third factor - crop protection. The content of four micronutrients: iron, manganese, zinc and copper in winter spelt grain was differentiated by varietal factor. Compared varieties did not differentiate the amount of nickel in winter spelt grain. The 'Schwabenpeltz' cv. was more abundant than 'Rokosz' cv., which was mainly due to clearly higher iron concentration in the grains of German variety. The weight ratio of $\mathrm{Fe}: \mathrm{Mn}$ in winter spelt grain of 'Schwabenspelz' cv. was 2.7, which may indicate a lack of manganese while excess of iron. Increasing the plant density resulted in a statistically proven reduction of iron, manganese and zinc contents in winter spelt grain, and it had no effect on abundance of spelt grain with respect to copper and nickel. The results obtained in the experiment showed no significant effect of the crop protection method on microelements contents in winter spelt grain with the exception of copper. The use of herbicides at increased rate reduced the amount of copper below $3 \mathrm{mg} \mathrm{Cu} \cdot \mathrm{kg}^{-1} \mathrm{DM}$.
\end{abstract}

